\title{
COVID-19 SÜRECINDE OKUL MÜDÜRLERININ TEKNOLOJIK LIDERLIĞi
}

\section{ARASTTIRMA MAKALESI}

\section{Selçuk TURAN ${ }^{1}$}

1 Dr. Öğr. Üyesi, Zonguldak Bülent Ecevit Üniversitesi, selcukturan25@gmail.com, ORCID: 0000-0003-2234-6494.

Öz: Bu araştırmanın amac1, COVID-19 sürecinde okul müdürlerinin sergilediği teknolojik liderlik davranışlarını incelemektir. Araştırmada nitel araştırma yaklaşımı benimsenmiş olup durum çalışması yürütülmüştür. Araştırmanın çalışma grubunu, 2019-2020 eğitim-öğretim yılında Zonguldak ilindeki ilkokul, ortaokul ve liselerde görev yapan 13 okul müdürü oluşturmaktadır. Araştırmada veri toplama aracı olarak araştırmacı tarafından geliştirilen yarı yapılandırılmış görüşme formu kullanılmıştır. Araştırma verileri, okul müdürleriyle yapılan yüz yüze görüşmelerle toplanmıştır. Verilerin analizinde, nitel araştırma yöntemlerinden içerik analizi tekniği kullanılmıştır. Araştırmanın bulguları, okul müdürlerinin COVID-19 sürecinde, eğitim teknolojileri yoluyla uzaktan eğitimi yönetirken müfredatın devamını sağlamayı, öğrencilerin okuldan kopmamalarını sağlamayı ve öğretmenlerin teknoloji konusunda mesleki gelişimlerini desteklemeyi amaçladıklarını göstermektedir. Araştırma bulguları ayrıca okul müdürlerinin, öğrencilerin teknolojik kaynaklara erişiminde eşitliği sağlamak için evinde interneti olmayan öğrencilere basılı kaynaklar sağladığını, teknolojik araç gereç temin ettiklerini, Eğitim Bilişim Ağı kullanımı konusunda destek sağladıklarını göstermektedir.

Anahtar Kelimeler: COVID-19, teknolojik liderlik, okul müdürü, uzaktan eğitim, EBA 


\title{
TECHNOLOGICAL LEADERSHIP OF SCHOOL PRINCIPALS DURING THE COVID-19 PERIOD
}

\begin{abstract}
:
The aim of this research is to examine the technological leadership behaviors of school principals during the COVID-19 period. Qualitative research approach was adopted in the research and a case study was conducted. The study group of the research consists of 13 school principals working in primary, secondary and high schools in Zonguldak province in the 2019-2020 academic year. The semi-structured interview form developed by the researcher was used as the data collection tool in the study. Research data were collected through face-to-face interviews with school principals. Content analysis technique, one of the qualitative research methods, was used in the analysis of the data. The findings of the study show that school principals aim to ensure the continuity of the curriculum, to ensure the students' commitment to school and to support teachers' professional development in technology while managing distance education through educational technologies during the COVID-19 period. The research findings also show that school principals provide printed resources to students who do not have internet at home, provide technological tools, and provide support for the use of Education Information Network in order to ensure equality in students' access to technological resources.
\end{abstract}

Key Words: COVID-19, technological leadership, school principal, distance education, Educational Informatics Network (EBA)

\section{Giriş}

Z kuşağının okullaşması ile birlikte eğitimde teknoloji kullanımının önemi artmıştır (Cilliers, 2017; Somyürek, 2014). Yapılan araştırmalar, okullarda teknoloji kullanımının öğrenci başarışına olumlu katkılarını ortaya koymaktadır (Chen, Lambert ve Guidry, 2010; Greaves, Hayes, Wilson, Gielniak ve Peterson, 2012; Li ve Ma, 2010). Ancak, öğretmenlerin ve okul müdürlerinin okullarda teknoloji kullanımına ilişkin güçlükler yaşadığı görülmektedir (Çalık, Çoban ve Özdemir, 2019; Hero, 2020). Özellikle COVID-19 küresel salgını nedeniyle yüz yüze eğitime ara verilen dönemde okul müdürlerinin nasıl bir liderlik sergiledikleri soru işaretidir (Harris, 2020). Bu güçlüklerin ortadan kaldırılması noktasında okul müdürünün hangi davranışları sergilemesi gerektiği açıklığa kavuşturulmayı beklemektedir. COVID-19'un liderlik anlayışını dramatik bir şekilde değiştirdiğini belirten Harris (2020), okul müdürlerinin bu süreç- 
te okulları bilgisayarları üzerinden yönettiklerini dile getirmektedir. Eğitim-öğretimin büyük oranda teknoloji yoluyla uzaktan yürütüldüğü COVID-19 sürecinde okul müdürlerinin tutum ve davranışlarının incelenmesi gereklilik olarak ortaya çıkmaktadır.

COVID-19 küresel salgının kamusal alanda etkilediği kurumların başında eğitim kurumları gelmektedir. Türkiye, sınırları içerisinde ilk vakanın görüldüğü 11 Mart 2020 tarihinden yalnızca 5 gün sonra, Millî Eğitim Bakanlığına (MEB) bağlı tüm örgün eğitim kurumlarında yüz yüze eğitime ara vererek, 23 Mart 2020 tarihinde eğitim-öğretim faaliyetlerini uzaktan eğitim yoluyla yürütmeye başlamıştır (MEB, 2020). MEB'e bağlı tüm örgün eğitim kurumlarında 2019-2020 eğitim-öğretim yılının ikinci döneminde eğitim-öğretim faaliyetleri kurumların belirlediği uzaktan eğitim platformları aracılığılyla gerçekleşmiştir. Bir milyonun üzerindeki öğretmen ve 18 milyonun üzerinde öğrenci Millî Eğitim Bakanlığı'nın belirlediği çerçeve ve programlar kapsamında sürece dâhil olmuştur. Öğrenciler derslerini, MEB tarafından kurulan sosyal nitelikli eğitsel elektronik içerik ağı Eğitim Bilişim A $\breve{g ̆}_{1}$ (EBA) platformu aracılığıyla hem internet ortamında, hem de Türkiye Radyo Televizyon Kurumu (TRT) aracılığıyla televizyon yayınları üzerinden takip etmiştir. Bununla birlikte, okulların hazırladığı programlar kapsamında öğretmenler de EBA aracılığıyla derslerini canlı olarak uzaktan eğitim yoluyla sürdürmüştür. Bu durum, bilgi ve teknoloji çağ1 olarak nitelendirilen 21. Yüzyılda öğretmen ve okul müdürlerinin teknoloji kullanımı konusunda yeterliklerinin ne denli önemli olduğunu ortaya koymuştur. Uzaktan eğitim sürecine ilişkin ders programlarının hazırlanması, öğretmenlerin ve öğrencilerin sürece dâhil edilmesi ve öğretimin eşgüdümlenmesi okul müdürlerinin liderliğinde gerçekleştirilmiştir. Bunun yanında, pandemi süreci içerisinde öğretmenlerin mesleki gelişimlerini de dikkate alan MEB, United Nations Educational, Scientific and Cultural Organization (Birleşmiş Milletler Eğitim Bilim ve Kültür Örgütü-UNESCO) ile işbirliği yaparak, farklı konularda öğretmenlerin mesleki gelişimleri ile ilgili uzaktan eğitim yoluyla hizmet içi eğitim seminerleri düzenlemiştir (Özer, 2020). Geçici bir süre için bile olsa bu salgın, okulda eğitimi durdurmuştur ve yakın zamana kadar destekleyici öğrenme seçenekleri olarak görülen, çevrim içi öğrenme, harmanlanmış öğrenme ya da uzaktan öğrenme artık eğitimi küresel olarak ifade eden elementler haline gelmiştir (Harris, 2020). Bu anlamda teknoloji kullanımın okullarda daha da önemli hale geldiği söylenebilir.

\section{Okul Müdürlerinin Teknolojik Liderliği}

Topluma nitelikli insan kaynağı sağlayan eğitim örgütlerinin varlığını sürdürebilmesi, çevresine ve çevresindeki değişimlere karşı gösterdiği uyuma bağlıdır. Bu değişimler arasında öne çıkan konulardan birisi ise teknolojidir. Teknolojiyi kullanabilen bireyler yetiştirmek, okulun açmaları arasındadır (Durnalı ve Akbaşl1, 2020). Bugünün eğitim anlayışı okul müdürlerinin kendilerini yalnızca eğitim liderleri olarak değil, yeni bilgi teknolojilerini ve uygulamalarını kullanan teknoloji liderleri olarak da yetiştirmelerini gerekli kılmaktadır (Beytekin, 2014). Konu okullar açısından ele alındığında, teknolojik gelişmelerin öğrenme ortamlarına entegrasyonunda en büyük sorumlu- 
luklardan biri de okul müdürlerine düşmektedir (Çalık vd., , 2019). Okulların, öğrenen örgütler olarak ne denli karmaşık yapılar oldukları göz önüne alındığında, teknolojik liderlik yalnızca kaynak sağlama ve bu kaynakları yönetmekten çok daha fazlasını ifade etmektedir (Flanagan ve Jacobsen, 2003). Teknolojik liderlik, yöneticilerin teknolojiyi uygulamada daha etkin rol oynadığı ve insanı ve bilgi teknolojisi bileşenlerini buluşturmaya çabaladığı liderlik ve teknoloji arasındaki ilişkidir (Hamzah, Nordin, Jusoff, Karim ve Yusof, 2010). Anderson ve Dexter (2005)'a göre teknolojik liderlik, örgütsel kararlar, politikalar ve teknoloji uygulamaları dâhil olmak üzere okulda teknoloji le ilgili tüm etkinlikleri içerir.

Flanagan ve Jacobsen (2003)' a göre teknolojik lider olarak okul müdürünün, teknolojinin okulla entegrasyonuna engel teşkil edebilecek şu dört konuyu dikkate alması lazım; pedagojik konular, eşitlik konusu, öğretmenlerin yetersiz mesleki gelişimi ve liderin yetersiz eğitimi. Lider, öğretmenin teknolojiyi müfredatla, anlamlı, zorlu ve özgün şekilde bütünleştirmenin yollarını keşfederken ve tecrübe ederken onu desteklemelidir. Teknolojik lider olarak okul müdürü, öğretmenlerin teknoloji konusunda mesleki gelişimlerini desteklemeli ve kendisini de bu konuda geliştirmelidir (Flanagan ve Jacobsen, 2003)

Amerika merkezli, International Society for Technology in Education (Eğitimde Uluslararası Teknoloji Topluluğu-ISTE) eğitim alanında standartlar geliştiren ve kar amacı gütmeyen bir sivil toplum örgütüdür. ISTE, eğitimin paydaşları olan, öğretmen, öğrenci ve eğitim koçlarına yönelik teknoloji standartları belirlemekte ve bu standartları belirli dönemlerde güncellemektedir. ISTE'nin geliştirmiş olduğu bu standartlar günümüzde yaklaşık 40 ülke tarafından kullanılmaktadır (Gökbulut ve Çoklar, 2017). ISTE ilk olarak 2002 yılında okul yöneticileri için National Educational Technology Standards for Administrators (Yöneticiler İçin Ulusal Eğitim Teknolojileri Standartları-NETS-A) standartlarını geliştirmiş, bu standartları 2009 yılında güncellemiştir (Durnalı, 2018). NETS-A teknoloji liderliği konusunda yapılan en kapsamlı çalışmalardan birisidir (Hafızoğlu, Karadeniz ve Dalgıç, 2011). ISTE, 2018 yılında yaptığı son güncellemeyle birlikte NETS-A (ISTE-2009) olarak bilinen teknoloji liderliği standartların The Education Leader Standarts (Ĕ̈itim Liderleri Standartları) başlı̆̆ 1 altında 5 madde de toplamıştır. ISTE'ye göre bir eğitim lideri; eşit vatandaşlı̆̆ı savunmalı, planlamada vizyon sahibi olmalı, güçlendirici liderlik yapmalı, sistem tasarımcısı olmalı ve sürekli öğrenmeyle ilişkili olmadır (ISTE, 2018). Bunlar:

1. Eşit Vatandaşhı̆̆ı Savunmak: Eğitim liderleri öğrencilerin, sınıf ortamında teknolojiyi etkin bir şekilde kullanan yetenekli öğretmenlere sahip olmalarını, özgün ve ilgi çekici öğrenme fırsatlarına katılmak için gerekli olan teknolojiye erişimlerini sağlar ve kendisi de dijital kaynakları etkin bir şekilde kullanarak ve bu kaynakları eleştirel bir şekilde değerlendirerek bir dijital vatandaşlık modeli çizer. 
2. Vizyoner Planlayıcı: Eğitim liderleri, tüm paydaşlarla iş birliği yaparak teknoloji kullanımı yoluyla öğrenci başarısını arttırmak için ortak bir vizyon geliştirilmesini sağlar.

3. Güçlendirici Lider: Eğitim liderleri, öğretmen ve öğrencilerin, eğitim ve öğretimi zenginleştirmek için teknolojiyi yenilikçi yollarla kullanmaları konusunda güçlendirildikleri bir iklim yaratır.

4. Sistem Tasarımcısı: Eğitim liderleri, öğrenme ortamlarında teknolojinin etkin bir şekilde kullanımını destekleyen kaynakların yeterli ve gelecekteki talepleri karşılamak için geliştirilebilir olmasını sağlar.

5. Ö̈̆grenmeye Bağhlık: Eğitim liderleri, kendileri ve diğerleri için teknolojiyle ilgili mesleki öğrenme etkinliklerini destekler. (ISTE, 2018)

COVID-19 süreci ile birlikte okul müdürlerinin liderlik rollerinin nasıl şekillendiğine ilişkin çalışmalar yürütülmeye başlanmıştır. Bu çalışmalardan birisi de Harris (2020) tarafından yürütülmüştür. Harris (2020), kriz dönemi olarak tanımlanan pandemi sürecinde, okul müdürlerinin değişen liderlik rollerini ve uygulamalarını, dağıtımcı liderlik, işbirlikçi liderlik ve ağ tabanlı uygulamalar bağlamında incelemiştir. COVID-19 sürecinde hem ilkokul, hem ortaokul hem de lise okul müdürleri, teknoloji kültürünün okullarında yaygınlaştırılması konusunda sıkıntılar yaşamaktadırlar. Kriz döneminde okul müdürlerinin nasıl hareket ettiğini betimleyen çalışmalara daha fazla ihtiyaç vardır. Alanyazın incelendiğinde, teknolojik liderliğe ilişkin yapılan birçok araştırmada ISTE standartlarının temel alındığı anlaşılmaktadır. (Akbaba, Altun ve Gürer, 2008; Anderson ve Dexter , 2005; Aksoy ve Çobanoğlu, 2018; Banoğlu, Vanderlinde ve Çetin, 2016; Chang, 2012; Çalık vd., 2019; Esplin, Stewart, Thurston, 2018; Gökbulut ve Çoklar, 2017; Görgülü ve Küçükali, 2018; Gürfidan ve Koç, 2016; Hac1fazlığlu vd., 2011). Ancak bu araştırmaların büyük çoğunluğunun nicel araştırma yöntemleri ile yürütüldügü görülmüştür. Bu nedenle, konu ile ilgili daha derinlemesine bulgulara ulaşmak için araştırma da nitel araştırma yöntemi kullanılmıştır. Bu noktadan hareketle, bu araştırmanın amacı, COVID-19 sürecinde okul müdürlerinin teknolojik liderlik davranışlarını incelemektir. Bu amaç cümlesine yönelik derinlemesine tespitler yapmak amacıyla, ISTE $(2009,2018)$ standartlarından faydalanılarak aşağdaki alt problemler belirlenmiştir:

1. Okul müdürlerinin, COVID-19 sürecinde, eğitim teknolojileri yoluyla uzaktan eğitimi yönetmek için belirledikleri amaçlar nelerdir?

2. Okul müdürlerinin, COVID-19 sürecinde, eğitim teknolojileri yoluyla uzaktan eğitimi yönetmek için belirledikleri amaçlara ulaşmalarını engelleyen unsurlar nelerdir?

3. Okul müdürleri COVID-19 sürecinde, öğretmen ve öğrencilere teknoloji kullanımı noktasında nasıl destek sağlamışlardır? 
4. Okul müdürleri, COVID-19 sürecinde uzaktan eğitime erişimde öğrencilerin teknolojik kaynaklara erişimi noktasında eşitliği sağlamak için neler yapmışlardir?

5. Okul müdürleri, COVID-19 sürecinde öğrencilerin uzaktan eğitime katılmasını sağlamak için velilerle nasıl iş birliği yapmışlardır?

6. Okul müdürleri, COVID-19 sürecinde uzaktan eğitim sürecini nasıl izlemiştir?

Bu araştırma, okul müdürleriyle yapılan doğrudan görüşmeler yoluyla COVID-19 döneminde okul müdürlerinin uzaktan eğitim sürecini nasıl organize ettiklerine, veli ve öğretmenlerle nasıl işbirliği kurduklarına, teknolojik kaynakların kullanımı noktasında hangi rol ve sorumlulukları üstlendiklerine, süreç içerisinde ne gibi sorunlarla karşılaştıklarına, kısaca eğitim öğretim faaliyetlerini uzaktan eğitim yoluyla nasıl yürüttüklerine yönelik veri sağlamayı amaçlamıştır. Bu açıdan, araştırma sonuçlarının uygulayıcılara ve politika yapıcılara bilgi sunması ve alana katkı sağlaması beklenmektedir. Araştırmanın sınırları okul müdürleri olarak belirlenmiştir dolayısıyla, öğretmen, öğrenci ve veliler bu araştırmanın kapsamı dâhilinde değildir.

\section{Yöntem}

Bu başlık altında, araştırmanın modeli, çalışma grubu, veri toplama aracı, verilerin toplanması ve verilerin analizi ile ilgili bilgilere yer verilmiştir.

\section{Araştırmanın Modeli}

Araştırma, COVID-19 sürecinde okul müdürlerinin teknolojik liderlik rollerini okul müdürleriyle yapılan yüz yüze görüşmelere dayalı olarak incelemeyi amaçladığ1 için çalışmada nitel araştırma deseninden yararlanılmıştır. "Nitel araştırma, gözlem, görüşme ve doküman analizi gibi nitel veri toplama yöntemlerinin kullanıldığı, algıların ve olayların doğal ortamda gerçekçi ve bütüncül bir biçimde ortaya konmasına yönelik bir sürecin izlendiği araştırmadır" (Yıldırım ve Şimşek, 2011, s.39).

\section{Çalışma Grubu}

Araştırmanın çalışma grubunu, 2019-2020 eğitim-öğretim yılında Zonguldak ilindeki ilkokul, ortaokul ve liselerde görev yapan 13 okul müdürü oluşturmaktadır. Çalışma grubu oluşturulurken amaçlı örnekleme yöntemlerinden olan maksimum çeşitlilik örnekleme yöntemine başvurulmuştur. Maksimum çeşitlilik örneklemesindeki amaç, küçük bir örneklem oluşturup buna dayalı olarak araştırma problemine taraf olan kişilerin çeşitliliğini arttırarak (Yıldırım ve Şimşek, 2011) benzeşik farklı durumların belirlenip araştırmanın bu durumlar üzerinden yürütülmesidir. (Büyüköztürk, Kılıç-Çakmak, Akgün, Karadeniz ve Demirel, 2018 ). Bu doğrultuda araştırmaya kat1lan okul müdürleri seçilirken tek bir eğitim kademesi yerine, ilkokul, ortaokul ve lise gibi farklı eğitim kademeleri seçilmiştir. Ayrıca okul müdürlerinin mesleki kıdem ve bulundukları okulda çalışma süreleri açısından da çeşitlilik oluşturulmaya çalışılmıştır. Tablo 1'de çalışma grubuna ait demografik bilgiler yer almaktadır. 
Tablo 1. Çalışma Grubuna Ait Demografik Bilgiler

\begin{tabular}{lllll}
\hline Katılımc1 & Cinsiyet & Okul Türü & $\begin{array}{l}\text { Mesleki } \\
\text { Kidem }\end{array}$ & $\begin{array}{l}\text { Okuldaki Görev } \\
\text { Süresi }\end{array}$ \\
\hline M1 & E & Ortaokul & 17 & 2 \\
\hline M2 & E & İlkokul & 22 & 7 \\
\hline M3 & E & Ilkokul & 16 & 8 \\
\hline M4 & E & Lise & 18 & 3 \\
\hline M5 & K & Ortaokul & 15 & 4 \\
\hline M6 & E & Lise & 17 & 4 \\
\hline M7 & E & Lise & 16 & 2 \\
\hline M8 & E & Lise & 23 & 5 \\
\hline M9 & E & Ortaokul & 11 & 8 \\
\hline M10 & K & Ortaokul & 12 & 7 \\
\hline M11 & E & İkokul & 15 & 2 \\
\hline M12 & E & Ortaokul & 17 & 1 \\
\hline M13 & E & Lise & 14 & \\
\hline
\end{tabular}

Tablo 1 incelendiğinde, araştırmaya katılan okul müdürlerinin büyük çoğunluğunun ( $\mathrm{f}=11$ ) erkek olduğu anlaşılmaktadır. Yine aynı tabloya göre, araştırmaya katılan okul müdürlerinin büyük çoğunluğu ortaokul $(\mathrm{f}=5)$ ve liselerde $(\mathrm{f}=5)$ görev yapmaktadır. Tablo 1 incelendiğinde, araştırmaya katılan okul müdürlerinin tamamının (\%100) 10 yıl ve üzeri mesleki kıdeme sahip olduğu anlaşılmaktadır.

\section{Verilerin Toplanmasi}

Araştırmada veri toplama aracı olarak araştırmacı tarafından geliştirilen yarı yapılandırılmış görüşme formu kullanılmıştır. Yarı yapılandırılmış görüşme formları yapılandırılmış formlara oranla katılımcıya ve araştırmacıya daha fazla esneklik sağlar, katılımcıların konuya ilişkin ayrıntılı görüşlerine ulaşmak isteyen araştırmacılar yarı yapılandırılmış görüşmeleri tercih eder (Smith, 1995). Görüşme formu hazırlanırken ISTE 2009 Yöneticiler İçin Ulusal Eğitim Teknolojileri Standartları-NETS-A ve 2018 Eğitim Liderleri Standartları dikkate alınarak sorulara ilişkin kavramsal bir çerçeve ve buna dayalı olarak da araştırma sorularının sınırları belirlenmiştir. Bu bağlamda yarı yapılandırılmış formu oluşturacak sorular için 6 ana tema belirlenmiştir. Bu temalar; amaç belirleme, amaçları engelleyen unsurlar, teknolojik destek, eşitliği sağlama, velilerle işbirliği, uzaktan eğitimi izleme şeklindedir. Belirlenen bu temalar soru ifadesine dönüştürülerek 6 sorudan oluşan bir yarı yapılandırılmış görüşme formu elde edilmiştir. Soruların kapsam geçerliliğine ilişkin görüş almak için üç alan uzmanıyla (birisi bilgisayar ve öğretim teknolojileri eğitimi, diğer ikisi eğitim yönetimi alanında öğretim üyesi), 
dil geçerliliği konusunda uzman görüşü almak için ise Türkçe eğitimi alanında bir öğretim üyesiyle görüşülmüştür. Uzmanlardan gelen dönütler neticesinde görüşme formuna son hali verilmiştir. Veri toplama sürecine başlamadan önce yarı yapılandırılmiş görüşme formunda yer alan sorular üç okul müdürüne sorulmuş. Yapılan bu ön görüşme sonunda elde edilen bulgular eş zamanlı olarak araştırmacı ve iki ayrı alan uzmanı tarafından incelenmiş ve veri toplama aracının işlevsel olduğuna ve araştırmaya uygun olduğuna karar verilmiştir. Veri toplama sürecinde, araştırmaya gönüllü olarak katılabileceklerini beyan eden ve kendilerinden önceden randevu alınan 13 okul müdürüyle yüz yüze görüşmeler yapılarak veriler toplanmıştır. Araştırmaya katılan okul müdürlerine araştırmanın amacı ve içeriği önceden açık bir şekilde anlatılmıştır. Görüşmeler yaklaşık 25-30 dakika sürmüştür. Katılımcıların sorulara verdikleri yanıtlar araştırmacı tarafından not edilmiş ve araştırma sonunda katılımcıların onayına sunulup doğruluğuna ilişkin kendilerinden onay alınmıştır. Veri toplama aracı olarak kullanılan yarı yapılandırılmış görüşme formuna ilişkin sorular şu şekildedir:

1. COVID-19 sürecinde, eğitim teknolojileri yoluyla uzaktan eğitimi yönetmek için hangi amaçları belirlediniz?

2. COVID-19 sürecinde, eğitim teknolojileri yoluyla uzaktan eğitimi yönetmek için belirlediğiniz amaçlara ulaşmanızı engelleyen unsurlar nelerdir?

3. COVID-19 sürecinde, öğretmen ve öğrencilere teknoloji kullanımı noktasında nasıl destek sağladınız?

4. COVID-19 sürecinde, uzaktan eğitime erişimde öğrencilerin teknolojik kaynaklara erişimi noktasında eşitliği sağlamak için neler yaptınız?

5. COVID-19 sürecinde, öğrencilerin uzaktan eğitime katılmasını sağlamak için velilerle nasıl işbirliği yaptınız?

6. COVID-19 sürecinde, uzaktan eğitimi nasıl izlediniz?

\section{Verilerin Analizi}

Verilerin analizinde, nitel araştırma yöntemlerinden içerik analizi tekniği kullanılmıştır. İçerik analizi, belirli olayları açıklamak ve ölçmek için sözel, görsel ya da yazılı verilerden, sistematik ve nesnel bir biçimde çıkarımlar yapmayı sağlayan bir araştırma modelidir (Downe, 1992). İçerik analiz sürecinde, her bir alt problem kapsamında elde edilen veriler dikkatli bir incelemeden geçirilerek kodlar oluşturulmuştur ve bu kodlar ilgili kategoriler altında toplanmıştır. Benzer kategoriler altında oluşturulan bu kodların güvenilirliğini sağlamak için veriler biri bilgisayar ve öğretim teknolojileri eğitimi, diğeri eğitim yönetimi alanında uzman olan iki öğretim üyesine gönderilerek kendilerinden verileri benzer kategoriler altında kodlamaları istenmiştir. Uzman dönütleri alındıktan sonra araştırmacı ve uzmanların kodlamaları arasındaki görüş birliği / ayrılığı Miles ve Huberman'ın (1994) formülüyle hesaplanmıştır. Güvenirlik=görüş birliği sayısı/ (görüş birliği sayısı+ görüş ayrılığı sayısı). Buna göre araştırmacı 
ve uzman görüşleri arasında \%92'lik bir görüş uyumuna ulaşılmıştır. Nitel araştırmalarda uzman görüşleri arasındaki bu uyumun \%90 ve üzeri olması beklenmektedir (Saban, 2008). Görüşlerine başvurulan okul müdürlerinin isimleri gizli tutulduğundan her bir okul müdürü için bir kod belirlenmiştir (M1, M2, M3...M13). Araştırma kapsamında elde edilen bulgular tablolar halinde sunulmuştur. Tablo başlıkları ilgili araştırma problemini yansıtacak şekilde belirlenmiştir. Tablolarda yanıt aranan probleme ilişkin tema, kod, katılımcı, katılımcı görüş örnekleri ve frekans bilgilerine yer verilmiştir. Her tablonun altında bulgular deşifre edilmiştir.

\section{Bulgular}

1. Okul müdürlerinin, COVID-19 sürecinde, eğitim teknolojileri yoluyla uzaktan eğitimi yönetmek için belirledikleri amaçlar

Araştırmanın birinci alt problemi kapsamında okul müdürlerine; COVID-19 sürecinde, eğitim teknolojileri yoluyla uzaktan eğitimi yönetmek için hangi amaçları belirlediniz? sorusu yöneltilmiştir. Okul müdürlerinin bu soruya ilişkin görüşlerinden elde edilen bulgular Tablo 2'de gösterilmektedir. 


\section{Covid-19 Sürecinde Okul Müdürlerinin Teknolojik Liderliği}

Tablo 2. Okul müdürlerinin, COVID-19 sürecinde, eğitim teknolojileri yoluyla uzaktan eğitimi yönetmek için belirledikleri amaçlar

\begin{tabular}{|c|c|c|c|c|}
\hline Tema & Kodlar & Katılımcılar & Müdür Görüş Örnekleri & $\mathbf{f}$ \\
\hline \multirow{8}{*}{ 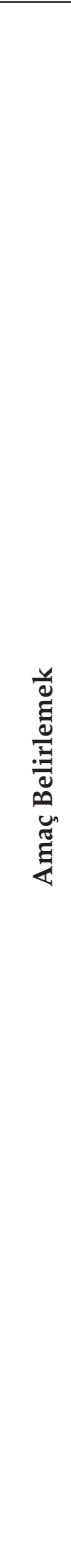 } & $\begin{array}{l}\text { Müfredatın devamını } \\
\text { sağlamak }\end{array}$ & $\begin{array}{l}\text { M3,M4,M6,M7, } \\
\text { M8,M9,M11, } \\
\text { M12, M13 }\end{array}$ & $\begin{array}{l}\text { 'Bildiğiniz gibi Mart } 2020 \text { başında yüz } \\
\text { yüze eğitime ara verildi. Biz öncelikli ola- } \\
\text { rak eğitim-öğretim müfredatın sürdür- } \\
\text { meyi amaç edindik." (M.13) }\end{array}$ & 9 \\
\hline & $\begin{array}{l}\text { Öğrencilerin okuldan } \\
\text { kopmamalarını } \\
\text { sağlamak }\end{array}$ & $\begin{array}{l}\text { M4,M5,M6,M7, } \\
\text { M12,M3 }\end{array}$ & $\begin{array}{l}\text { "Öğrenciler yüz yüze eğitimle okula } \\
\text { devam etmeseler de okullarından, } \\
\text { sinıflarından ve derslerinden } \\
\text { kopmalarmı, uzaklaşmaların } \\
\text { önlemek" (M.4) }\end{array}$ & 6 \\
\hline & $\begin{array}{l}\text { Öğretmenlerin } \\
\text { teknoloji konusunda } \\
\text { mesleki gelişimlerini } \\
\text { desteklemek }\end{array}$ & M1, M2, M9 & $\begin{array}{l}\text { "COVID- } 19 \text { sürecinde farkh ortamlarda } \\
\text { bulunan öğretmenlerin teknolojik mesleki } \\
\text { yeterliliklerini artırmak için online semi- } \\
\text { ner ve kurslara katıllmların sağlamak." } \\
\text { (M.1) }\end{array}$ & 3 \\
\hline & $\begin{array}{l}\text { Akademik başarıyı } \\
\text { arttırmak }\end{array}$ & M10, M13 & $\begin{array}{l}\text { "Hepimizin ortak amacımı ö̆grencileri- } \\
\text { mizin derslerinde başarılı olmasıdır. Işste } \\
\text { bu yüzden ilk önce öğrencilerin dersle- } \\
\text { rinde akademik olarak başarılı olmalarım } \\
\text { amaçladık." (M.10) }\end{array}$ & 2 \\
\hline & $\begin{array}{l}\text { Öğrencilerin } \\
\text { ihtiyaçlarını } \\
\text { karşılamak için } \\
\text { öğretmenleri } \\
\text { güdülemek }\end{array}$ & M2 & $\begin{array}{l}\text { "Tüm öğrenciler ile birebir iletişim kura- } \\
\text { rak öğrenim gereksinimlerini karşılama- } \\
\text { ları için öğretmenleri güdülemek." (M.2) }\end{array}$ & 1 \\
\hline & $\begin{array}{l}\text { Öğretmen ve } \\
\text { öğrencilerin uzaktan } \\
\text { eğitim sorunlarına } \\
\text { çözümler üretebilmek }\end{array}$ & M2 & $\begin{array}{l}\text { "Öğretmen ve öğrencilerin uzaktan } \\
\text { eğitim faaliyetlerinde yaşadıkları sorun- } \\
\text { lara anlık pratik çözümler üretebilmeyi } \\
\text { amaçladık" (M.2) }\end{array}$ & 1 \\
\hline & $\begin{array}{l}\text { Okul-veli iletişimini } \\
\text { sürdürmek }\end{array}$ & M4 & $\begin{array}{l}\text { "Okul idaresi, veli, öğretmen, öğrenci } \\
\text { iletişimini 7/24 kesintisiz sürdürmek..." } \\
\text { (M.4) }\end{array}$ & 1 \\
\hline & $\begin{array}{l}\text { Uzaktan eğitim kültü- } \\
\text { rü oluşturmak }\end{array}$ & M8 & $\begin{array}{l}\text { "İki amactmı vardı..... bir diğeri ise } \\
\text { okulumuzun vizyonunda var olan } \\
\text { teknoloji kullanım kültürünü uzak- } \\
\text { tan eğitim için de oluşturmaktır" } \\
\text { (M.8) }\end{array}$ & 1 \\
\hline
\end{tabular}


Tablo 2'de, okul müdürlerinin COVID-19 sürecinde eğitim teknolojileri yoluyla uzaktan eğitimi yönetmek için belirledikleri amaçlara ilişkin veriler yer almaktadır. Tablo 2 incelendiğinde, okul müdürlerinin neredeyse üçte ikisinin ( $f=9$ ) müfredatın devamını sağlamayı ve yaklaşık yarısının $(f=6)$, öğrencilerin okuldan kopmamasını amaçladığı anlaşılmaktadır. Okul müdürlerinin bu soruya verdikleri yanıtların sırasıyla en çok "öğretmenlerin teknoloji konusunda mesleki gelişimlerini desteklemek" $(\mathrm{f}=3)$, "akademik başarıyı arttırmak" ( $\mathrm{f}=2)$, " öğrencilerin teknolojik ihtiyaçlarını karşılamak için öğretmenleri güdülemek" (f=1), " öğretmen ve öğrencilerin uzaktan eğitim sorunlarına çözümler üretebilmek" ( $\mathrm{f}=1)$, " okul-veli iletişimini sürdürmek" ( $\mathrm{f}=1$ ) ve " uzaktan eğitim kültürü oluşturmak" ( $\mathrm{f}=1$ ) maddelerinde toplandığ1 görülmektedir.

2. Okul müdürlerinin, COVID-19 sürecinde, eğitim teknolojileri yoluyla uzaktan eğitimi yönetmek için belirledikleri amaçlara ulaşmalarını engelleyen unsurlar

Araştırmanın ikinci alt problemi kapsamında okul müdürlerine; COVID-19 sürecinde, eğitim teknolojileri yoluyla uzaktan eğitimi yönetmek için belirlediğiniz amaçlara ulaşmanızı engelleyen unsurlar nelerdir? sorusu yöneltilmiştir. Okul müdürlerinin bu soruya ilişkin görüşlerinden elde edilen bulgular Tablo 3'te gösterilmiştir. 


\section{Covid-19 Sürecinde Okul Müdürlerinin Teknolojik Liderliği}

Tablo 3. Okul müdürlerinin, COVID-19 sürecinde, eğitim teknolojileri yoluyla uzaktan eğitimi yönetmek için belirledikleri amaçlara ulaşmalarını engelleyen unsurlar

\begin{tabular}{|c|c|c|c|c|}
\hline Tema & Kodlar & Katılımcılar & Müdür Görüş Örnekleri & $\mathbf{f}$ \\
\hline \multirow{9}{*}{ 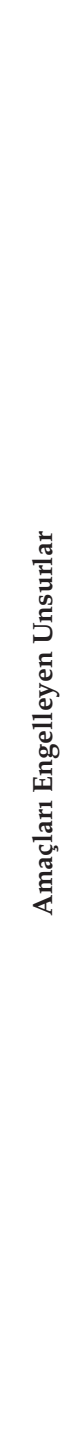 } & Teknik sorunlar & $\begin{array}{l}\text { M1, M2, M4, } \\
\text { M7, M10, } \\
\text { M13 }\end{array}$ & $\begin{array}{l}\text { "İlk günlerde EBA'ya bağlanırken sorun ya- } \\
\text { şadık. Sistemden kopma oluyordu. Kolay değil } \\
\text { milyonlarca öğrenci ve bir sürü öğretmen aynı } \\
\text { anda bağlanmaya çalışıyor. Sonra bakanlık } \\
\text { bunu iyileştirince sorun kalmadı."(M.7) }\end{array}$ & 6 \\
\hline & Veli duyarsızlı̆̆1 & $\begin{array}{l}\text { M2, M4, M6, } \\
\text { M9, M11 }\end{array}$ & $\begin{array}{l}\text { "Bazı veliler biraz bizi yordu bu konuda. } \\
\text { ilk başlarda iyiydi ama sonradan kopma- } \\
\text { lar yaşadık. Onlardan dönüt alamadık. } \\
\text { Genelleme yanlış olur ama ilgisiz veliler } \\
\text { oldu." (M.11) }\end{array}$ & 5 \\
\hline & $\begin{array}{l}\text { Öğrencilerin } \\
\text { sosyo-ekonomik } \\
\text { durumu }\end{array}$ & $\begin{array}{l}\text { M1,M4,M8, } \\
\text { M13 }\end{array}$ & $\begin{array}{l}\text { "Başka bir neden olarak teknolojik imkanlara } \\
\text { sahip olmayan ögrenciler onlar takip edemedi } \\
\text { düzenli olarak." (M.8) }\end{array}$ & 4 \\
\hline & $\begin{array}{l}\text { Mesleki kıdemi } \\
\text { yüksek olan } \\
\text { öğretmenlerin } \\
\text { teknolojiden uzak } \\
\text { olması. }\end{array}$ & $\begin{array}{l}\text { M3,M5,M6, } \\
\text { M7 }\end{array}$ & $\begin{array}{l}\text { "Yaşlı demeyelim ama meslekte tecrübeli bazı } \\
\text { ögretmenlerin teknoloji kullanmaya dönük } \\
\text { yetersizliği de buna yol açmış olabilir." (M.3) }\end{array}$ & 4 \\
\hline & $\begin{array}{l}\text { Bazı öğretmenle- } \\
\text { rin uzaktan eğiti- } \\
\text { min yararlılığına } \\
\text { inanmaması }\end{array}$ & M8,M9,M13 & $\begin{array}{l}\text { "Uzaktan ĕ̆itimin faydalı olacağına inan- } \\
\text { mayan bazı ögretmen arkadaşlar fazla çaba } \\
\text { göstermedi" (M.8) }\end{array}$ & 3 \\
\hline & $\begin{array}{l}\text { Devamsızlık } \\
\text { sorunu }\end{array}$ & M4,M12 & $\begin{array}{l}\text { "Öğrencilerden kaynaklanan sebepler var. } \\
\text { Derslere katılmayan, devamsızlık yapan } \\
\text { ögrenciler vardı."(M.12) }\end{array}$ & 2 \\
\hline & $\begin{array}{l}\text { Anne-babanın } \\
\text { ders saatinde } \\
\text { evde olmama- } \\
\text { sindan kaynaklı } \\
\text { teknolojik araç } \\
\text { eksikliği }\end{array}$ & M4 & $\begin{array}{l}\text { "Anne veya babanın öğrencinin ders saatin- } \\
\text { de evde bulunmamast. Cep telefonunu yanına } \\
\text { almast". (M.4) }\end{array}$ & 1 \\
\hline & $\begin{array}{l}\text { Öğretmenin } \\
\text { aynı zamanda } \\
\text { veli olmasından } \\
\text { kaynaklanan } \\
\text { unsurlar }\end{array}$ & M4 & $\begin{array}{l}\text { "Uzaktan eğitimde ders veren öğretme- } \\
\text { nin aymı zamanda veli olması. Iletişim } \\
\text { aractmın hem öğrenci hem veli olan } \\
\text { ögrretmen tarafından kullanılması engel } \\
\text { teşkil etmiş̧ir." (M.4) }\end{array}$ & 1 \\
\hline & $\begin{array}{l}\text { Birden fazla kar- } \\
\text { deşin aynı anda } \\
\text { evdeki teknolojik } \\
\text { aletleri kullanması }\end{array}$ & M4 & $\begin{array}{l}\text { "Evde ayn iletişim aracının } 2 \text { veya } \\
\text { daha fazla kardeş tarafindan kullanilma- } \\
\text { si." (M.4) }\end{array}$ & 1 \\
\hline
\end{tabular}


Tablo 3'te, okul müdürlerinin, COVID-19 sürecinde, eğitim teknolojileri yoluyla uzaktan eğitimi yönetmek için belirledikleri amaçlara ulaşmalarını engelleyen unsura ilişkin bulgulara yer verilmiştir. Tablo 3 incelendiğinde, okul müdürlerinin, belirledikleri amaçlara ulaşmalarını engelleyen unsurların başında en çok sırasıyla "teknik sorunlar $(\mathrm{f}=6)$ ", , "velilerin duyarsızlığ $(\mathrm{f}=5)$ ", , "öğrencilerin sosyo ekonomik durumları $(\mathrm{f}=4)^{\prime \prime}$, "mesleki kıdemi yüksek olan öğretmenlerin teknolojiden uzak olması $(\mathrm{f}=3)$ " ve " bazı öğretmenlerin uzaktan eğitimin yararlılı̆̆ına inanmaması" gibi nedenleri gördükleri anlaşılmaktadır. Bunun yanında bazı okul müdürlerinin ( $\mathrm{f}=2$ ), öğrenci devamsızlığını bu sorunun nedenleri arasında gördüğü anlaşılmaktadır. Tablo 3'e göre, bir okul müdürünün, öğrencilerin, ebeveynlerinin ders saatinde evde olmamasından kaynaklı teknolojik araç eksikliği çekmesi, öğretmenin aynı zamanda veli olması ve birden fazla kardeşin aynı anda ev ortamında teknolojik aletleri kullanması nedeniyle ortaya çıkan sorunları, belirledikleri amaçlara ulaşmalarını engelleyen unsurlar gördüğü anlaşılmaktadır. Elde edilen bu bulguların dikkat çekici nitelikte olduğu değerlendirilmektedir.

\section{Okul müdürlerinin COVID-19 sürecinde öğretmen ve öğrencilere teknoloji kullanımı noktasında destek sağlaması}

Araştırmanın üçüncü alt problemi kapsamında okul müdürlerine; COVID-19 sürecinde öğretmen ve öğrencilere teknoloji kullanımı noktasında nasıl destek să̆ladınız? sorusu sorulmuştur. Okul müdürlerinin bu soruya ilişkin görüşlerinden elde edilen bulgular Tablo 4'te gösterilmiştir. 
Tablo 4. Okul müdürlerinin COVID-19 sürecinde öğretmen ve öğrencilere teknoloji kullanımı noktasında destek sağlaması

\begin{tabular}{|c|c|c|c|c|}
\hline Tema & Kodlar & Katılımcilar & Müdür Görüş Örnekleri & $\mathbf{f}$ \\
\hline \multirow{6}{*}{ 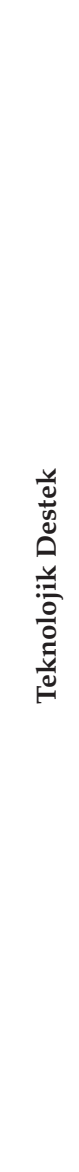 } & $\begin{array}{l}\text { Teknoloji kullanımın- } \\
\text { da öğretmene teknik } \\
\text { destek }\end{array}$ & $\begin{array}{l}\text { M4, M6, M8, } \\
\text { M9, M11, M12 }\end{array}$ & $\begin{array}{l}\text { "EBA ve zoom kullanmakta zorluk } \\
\text { çeken ögrretmenlerimize, daha önce } \\
\text { kullanma tecrübesi olan idareci ve öğ- } \\
\text { retmenlerimizin eşliğinde deneme otu- } \\
\text { rumlarn gerçekleştirildi."(M.4) }\end{array}$ & 6 \\
\hline & $\begin{array}{l}\text { Okul bilgisayarlarının } \\
\text { ögrretmenlerle payla- } \\
\text { ş1ması }\end{array}$ & $\begin{array}{l}\text { M1, M4, M6, } \\
\text { M10, M11 }\end{array}$ & $\begin{array}{l}\text { "...öğretmen ve öğrencilere teknoloji } \\
\text { kullanımı noktasında okul kaynakla- } \\
\text { rı ölçüsünde destek sağlandi. Şöyle } \\
\text { ki okulumdaki diz üstü bilgisayarlar } \\
\text { ögretmenlere verilerek süreci bulun- } \\
\text { dukları yerden takip etmeleri sağlan- } \\
\text { d.."(M.1) }\end{array}$ & 5 \\
\hline & $\begin{array}{l}\text { Bakanlık duyurularının } \\
\text { paylaşılması }\end{array}$ & M6, M7, M8 & $\begin{array}{l}\text { "Bakanliğın tüm paylaşımlarını whats- } \\
\text { app gruplarından öğretmenlerle paylaş- } \\
\text { tık."(M.6) }\end{array}$ & 3 \\
\hline & $\begin{array}{l}\text { Öğretmenlerin teknoloji } \\
\text { kullanımına yönelik } \\
\text { uzaktan hizmet-içi } \\
\text { eğitime yönlendirilmesi }\end{array}$ & M6, M7, M12 & $\begin{array}{l}\text { "Bakanlık Hizmet-içi kursu verdi EBA } \\
\text { kullanımı için, öğretmenlerimizi bu } \\
\text { kursa yönlendirdik." (M.7) }\end{array}$ & 3 \\
\hline & $\begin{array}{l}\text { Öğrencilerin EBA TV'ye } \\
\text { ve EBA canlı derse } \\
\text { yönlendirilmesi }\end{array}$ & M4, M8, M10 & $\begin{array}{l}\text { "EBA bizim ana kaynă̆ımı oldu. } \\
\text { EBA TV deki programları izlemeleri } \\
\text { için öğretmenlerden sorumlu oldukları } \\
\text { şubenin öğrencileriyle temasa geçme- } \\
\text { lerini ve takip etmelerini istedim. Aynı } \\
\text { zamanda EBA canlı derslere katılmalar } \\
\text { için velilerle de iletişim halinde olduk" } \\
\text { (M.10) }\end{array}$ & 3 \\
\hline & $\begin{array}{l}\text { Öğretmenler arasında } \\
\text { uzaktan eğitime yönelik } \\
\text { iyi örneklerin paylaş1- } \\
\text { mını sağlamak }\end{array}$ & M5,M13 & $\begin{array}{l}\text { "Öğretmenlerimiz gerek EBA üze- } \\
\text { rinden, gerek zoom üzerinden can- } \\
\text { lı dersler anlattı. Derslerde etkin- } \\
\text { likler yaptı. Öğretmenlerimizden } \\
\text { yaptıkları iyi örnekleri diğer arkadaşlar } \\
\text { paylaşmaların sağladım. Diğer ögret- } \\
\text { menlere örnek olsun diye." }(M, 13)\end{array}$ & 2 \\
\hline
\end{tabular}

Tablo 4'te, okul müdürlerinin COVID-19 sürecinde öğretmen ve öğrencilere teknoloji kullanımı noktasında nasıl destek sağladığına ilişkin müdürlerin görüşleri yer almaktadır. "Teknoloji kullanımında öğretmene destek" üzerinde en çok görüş bildirilen destek sağlama yöntemi olarak dikkat çekmektedir ( $\mathrm{f}=6$ ). Bunu "okul bilgisayarlarının öğretmenlerle paylaşılması" ( $\mathrm{f}=5$ ) takip etmektedir. Bazı okul müdürlerinin ( $\mathrm{f}=3$ ), "bakanlık duyurularının paylaşılması" maddesi üzerinde görüş birliğinde oldukları görülmektedir. Tablo 4 incelendiğinde, teknik destek sağlama konusunda "öğretmen- 
lerin teknoloji kullanımına yönelik uzaktan hizmet-içi eğitime yönlendirilmesi" görüşünü taşıyan okul müdürlerinin olduğu anlaşılmaktadır ( $\mathrm{f}=3$ ). "Öğrencilerin EBA TV'ye ve EBA canlı derse yönlendirilmesi" teknolojik destek sağlama noktasında okul müdürlerinin öğrencilere yönelik görüş bildirdiği tek konu olarak karşımıza çıkmaktadır (f=3). " Öğretmenler arasında uzaktan eğitime yönelik iyi örneklerin paylaşımını sağlamak" ise, teknolojik destek sağlamayla ilgili katılımcılar tarafından en az tercih edilen yöntemdir $(\mathrm{f}=2)$.

4. Okul müdürlerinin COVID-19 sürecinde uzaktan eğitime erişimde öğrencilerin teknolojik kaynaklara erişimi noktasında eşitliği sağlamak için sergiledikleri davranışlar

Araştırmanın dördüncü alt problemi kapsamında okul müdürlerine; COVID-19 sürecinde uzaktan eğitime erişimde öğrencilerin teknolojik kaynaklara erişimi noktasında eşitliği sağlamak için neler yaptınız? sorusu yöneltilmiştir.

Okul müdürlerinin bu soruya ilişkin görüşlerinden elde edilen bulgular Tablo 5'te gösterilmiştir. 
Tablo 5. Okul müdürlerinin COVID-19 sürecinde uzaktan eğitime erişimde öğrencilerin teknolojik kaynaklara erişimi noktasında eşitliği sağlamak için sergiledikleri davranışlar

\begin{tabular}{|c|c|c|c|c|}
\hline Tema & Kodlar & Katılımcılar & Müdür Görüş Örnekleri & $\mathbf{f}$ \\
\hline \multirow{6}{*}{ 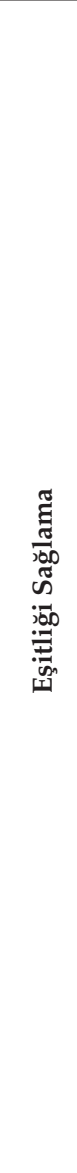 } & $\begin{array}{l}\text { İnternet erişimi olmayan } \\
\text { öğrencilerle ders } \\
\text { dokümanlarının paylaşımı }\end{array}$ & $\begin{array}{l}\text { M5,M6,M7, } \\
\text { M8,M12 }\end{array}$ & $\begin{array}{l}\text { "İki ögrrencimizin maddi nedenlerle ev- } \\
\text { lerine internet olmadıkların öğrendik. } \\
\text { Interneti olmayan veliler için de konu } \\
\text { içerikleriyle ilgili dokümanları veliler } \\
\text { ve öğrencilerle paylaştık."(M5) }\end{array}$ & 5 \\
\hline & $\begin{array}{l}\text { Okul tarafından ihtiyaç } \\
\text { sahibi öğrencilere teknolo- } \\
\text { jik araç temini }\end{array}$ & M4, M7, M11 & $\begin{array}{l}\text { "Eşitliği sağlamak pek mümkün olma- } \\
\text { dı ancak, } 2 \text { öğrencimize TV temin edil- } \\
\text { di. } 1 \text { öğrencimize tablet, } 1 \text { öğrencimize } \\
\text { akıll cep telefonu ulaştırıldı." (M4) }\end{array}$ & 3 \\
\hline & $\begin{array}{l}\text { Bakanlığın EBA için } \\
\text { ücretsiz internet sağ- } \\
\text { lamasının öğrencilere } \\
\text { duyurulması. }\end{array}$ & M8,M11 & $\begin{array}{l}\text { "Bakanlığımız EBA'YA girişler için tel } \\
\text { operasyonlarıla anlaşıp öğrencilere } 6 \\
\text { GB ücretsiz internet verdi. Bunu veli- } \\
\text { lerle paylaştık." (M8) }\end{array}$ & 2 \\
\hline & $\begin{array}{l}\text { EBA destek alanı oluş- } \\
\text { turma }\end{array}$ & M11,M13 & $\begin{array}{l}\text { "Bakanliğımız yakın zamanda internet } \\
\text { erişimi olmayan veya destek isteyen ço- } \\
\text { cuklarla ilgili bilgi istedi. Bu çocuklar } \\
\text { için okulda EBA teknik destek alanları } \\
\text { oluşturmamızı istedi. Biz de her sinıf } \\
\text { düzeyi için bilgisayar ve internet içeren } \\
\text { sinıflar oluşturduk." (M1) }\end{array}$ & 2 \\
\hline & $\begin{array}{l}\text { Engelli öğrenciler için özel } \\
\text { tedbirler }\end{array}$ & M7 & $\begin{array}{l}\text { "Bizim okulumuzda görme sıkıntısı } \\
\text { yaşayan bir öğrencimiz var. Bu öğren- } \\
\text { ci geride kalmasın diye özel tedbirler } \\
\text { aldık. Onun için özel program hazır- } \\
\text { ladık. Ö̆gretmenlerimiz daha büyü̈k } \\
\text { puntolarla hazırladıkları materyaller } \\
\text { üzerinden ona ders anlattı." (M7) }\end{array}$ & 1 \\
\hline & $\begin{array}{l}\text { EBA'ya ders dökümanı } \\
\text { yükleme }\end{array}$ & M6 & $\begin{array}{l}\text { "EBA 'da zaten sinıf grupları vardı. } \\
\text { Bunun yanında ögretmenlerin öğren- } \\
\text { cileriyle sürekli kaynak paylaşmasını } \\
\text { sağladık. Öğgretmenlerimiz anlattıkları } \\
\text { derslere ilişkin materyalleri bu sınıflara } \\
\text { yükledi, derse katılamayan öğrenciler } \\
\text { sonradan izlesin diye." (M6) }\end{array}$ & 1 \\
\hline
\end{tabular}

Tablo 5'te, okul müdürlerinin, kaynaklara erişim noktasında eşitliği sağlamak için gösterdikleri çabalara ilişkin veriler yer almaktadır. Tablo 5 incelendiğinde, okul müdürlerinin kaynaklara erişimde eşitliği sağlamak için en çok $(\mathrm{f}=5)$ "internet erişimi olmayan öğrencilerle ders dokümanlarının paylaşımı" görüşünü benimsediği anlaşılmaktadır. Bunu, " okul tarafından ihtiyaç sahibi öğrencilere teknolojik araç temini" $(\mathrm{f}=3)$, takip etmektedir. İki okul müdürünün (f=2), Bakanlığın EBA için öğrencilere 
ücretsiz internet sağlamasının öğrencilere duyurulmasını eşitliği sağlamak için sergiledikleri davranışlar kapsamında algıladıkları görülmektedir. Bunu, "EBA destek alanı oluşturma" (f=2) görüşü takip etmektedir. Tablo 5'e göre ayrıca bir okul müdürü $(\mathrm{f}=1)$ eşitliği sağlamak noktasında "engelli öğrenciler için özel tedbirler" almıştır. Son olarak kaynaklara erişimde eşitliği sağlama konusunda bir okul müdürünün $(f=1)$ " EBA'ya ders dökümanı yükleme" görüşünü belirttiği anlaşılmaktadır.

\section{Okul müdürlerinin COVID-19 sürecinde öğrencilerin uzaktan eğitime katıl- masını sağlamak için velilerle işbirliği yapma yolları}

Araştırmanın beşinci alt problemi kapsamında okul müdürlerine; COVID-19 sürecinde öğrencilerin uzaktan eğitime katılmasını să̆lamak için velilerle nasıl işbirliği yaptını?? sorusu yöneltilmiştir.

Okul müdürlerinin bu soruya ilişkin görüşlerinden elde edilen bulgular Tablo 6' da gösterilmiştir.

Tablo 6. Okul müdürlerinin COVID-19 sürecinde öğrencilerin uzaktan eğitime katılmasını sağlamak için velilerle işbirliği yapma yolları

\begin{tabular}{|c|c|c|c|c|}
\hline Tema & Kodlar & Katılımcilar & Müdür Görüş Örnekleri & $\mathrm{f}$ \\
\hline \multirow{2}{*}{ 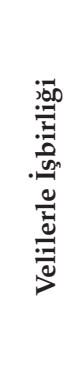 } & $\begin{array}{l}\text { Sosyal medya ve } \\
\text { telekomünikasyon } \\
\text { araçları yoluyla iş } \\
\text { birliği }\end{array}$ & $\begin{array}{l}\text { M1, M3, M4, } \\
\text { M5, M6, M7, } \\
\text { M8, M9, M13, }\end{array}$ & $\begin{array}{l}\text { "Süreci yönetmek için facebook, wats-app gu- } \\
\text { rupları ve diğer sosyal medya araçları yoluyla } \\
\text { veli ve öğretmenlerle iş birliği yapılarak öğren- } \\
\text { cilerin dersleri takibi sağlandt." (M13) }\end{array}$ & 9 \\
\hline & $\begin{array}{l}\text { Öğrenci ve velilere } \\
\text { PDR hizmeti }\end{array}$ & $\begin{array}{l}\text { M4,M8,M11, } \\
\text { M12 }\end{array}$ & $\begin{array}{l}\text { "Hem öğretmen hem de velilerimize daha çok } \\
\text { psikolojik olarak desteği öncelik vermeye ça- } \\
\text { lıştık. Rehberlik servisimiz velileri aradı, öğ- } \\
\text { rencilerin sorunların dinledi. Velilere de her } \\
\text { konuda bizi arayabileceklerini söyledik. Talep } \\
\text { eden velilere öğrencisi için özel destek sağlan- } \\
\text { d.." (M11) }\end{array}$ & 4 \\
\hline
\end{tabular}

Tablo 6'da, COVID-19 sürecinde okul müdürlerinin öğrencilerin uzaktan eğitime katılması için velilerle kurduğu işbirliğine ilişkin bulgular yer almaktadır. Buna göre okul müdürlerinin bu işbirliğini iki boyutta algıladıkları görülmektedir. Bunlardan ilki, okul müdürlerinin büyük bir çoğunluğunun ( $f=9$ ) ortak görüş bildirdiği " sosyal medya ve telekomünikasyon araçları yoluyla iş birliği" boyutudur. İlk boyuta oranla daha az sayıda okul müdürü ise bu işbirliğini " öğrenci ve velilere PDR hizmeti" yönünde algılamaktadır.

\section{Okul müdürlerinin COVID-19 sürecinde uzaktan eğitim sürecini izleme yolları}

Araştırmanın altıncı alt problemi kapsamında okul müdürlerine; COVID-19 sürecinde uzaktan eğitimi nasıl izlediniz? sorusu sorulmuştur. 
Okul müdürlerinin bu soruya ilişkin görüşlerinden elde edilen bulgular Tablo 7'de gösterilmiştir.

Tablo 7. Okul müdürlerinin COVID-19 sürecinde uzaktan eğitimi izleme yolları

\begin{tabular}{|c|c|c|c|c|}
\hline Tema & Kodlar & Katılımcılar & Müdür Görüş Örnekleri & $\mathrm{f}$ \\
\hline \multirow{6}{*}{ 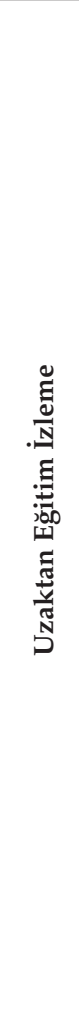 } & $\begin{array}{l}\text { EBA üzerinden alınan } \\
\text { raporlar }\end{array}$ & $\begin{array}{l}\text { M3, M4, M5, } \\
\text { M7, M9, M11, } \\
\text { M12 }\end{array}$ & $\begin{array}{l}\text { "EBA sistemi üzerinden kendilerine ders } \\
\text { tanımlanan öğrenci ve öğretmenlerin derse } \\
\text { katıllm ve geçirdikleri süreleri sürekli iz- } \\
\text { ledik. Eksik olan öğretmenlere telafi dersi } \\
\text { tanımladım. Bir de derse katılmayan öğ- } \\
\text { rencilerin velileri arandı ve ögrrencilerin } \\
\text { derslere devamı sağlandı" (M.5) }\end{array}$ & 7 \\
\hline & $\begin{array}{l}\text { Öğretmenlerden } \\
\text { alınan günlük-haf- } \\
\text { talık değerlendirme } \\
\text { raporları }\end{array}$ & $\begin{array}{l}\text { M1, M3, M6, } \\
\text { M7, M10, M13 }\end{array}$ & $\begin{array}{l}\text { "Derslere yönelik öğretmenlerden } \\
\text { haftallk ve bazı temel dersler için } \\
\text { günlük rapor istedik." (M.7) }\end{array}$ & 6 \\
\hline & $\begin{array}{l}\text { Öğretmenlerin sözlü } \\
\text { beyanları }\end{array}$ & $\begin{array}{l}\text { M2, M8, M9, } \\
\text { M11 }\end{array}$ & $\begin{array}{l}\text { "EBA raporlarm inceledim ve öğretmen- } \\
\text { leri her hafta aradım genel bilgi aldım." } \\
\text { (M.11) }\end{array}$ & 4 \\
\hline & $\begin{array}{l}\text { Müdürün, sınıfla- } \\
\text { rın canlı derslerine } \\
\text { katılması }\end{array}$ & M4 & $\begin{array}{l}\text { "Sinfların canlu derslerine yabancı uyruk- } \\
\text { lu devamsız öğrenci olarak dahil oldum." } \\
\text { (M.4) }\end{array}$ & 1 \\
\hline & $\begin{array}{l}\text { İyi uygulamaların } \\
\text { paylaşımı }\end{array}$ & M11 & $\begin{array}{l}\text { 'Öğretmenlerle birlikte Padlet uygu- } \\
\text { lamasında bir grup oluşturduk. Tüm } \\
\text { ögrretmenler uzaktan eğitimde işlediği } \\
\text { derslerle alakalı etkinlikleri buraya attl. } \\
\text { Öğretmenlerin neler yaptığın gördüm. }\end{array}$ & 1 \\
\hline & $\begin{array}{l}\text { Öğrenci ve velilerden } \\
\text { gelen dönütler }\end{array}$ & M1 & $\begin{array}{l}\text { ".......̈̈̆grencilerimizin, velilerimizin ve } \\
\text { ögretmenlerimizin sürece katkı vermesi, } \\
\text { gönülllü olmaları süreci yönetirken } \\
\text { aldığımız geri dönütlerin olumlu } \\
\text { karşılanması çalışmaların işleyiş̧ini } \\
\text { hızlandırdı." (M.1) }\end{array}$ & 1 \\
\hline
\end{tabular}

Tablo 7'de okul müdürlerinin uzaktan eğitim sürecini nasıl izlediğine yönelik veriler yer almaktadır. "EBA üzerinden alınan raporlar" en çok yer verilen izleme tekniği olarak dikkat çekmektedir (f=7). Bunu, sırasıyla "öğretmenlerden alınan günlük-haftalık değerlendirme raporları" (f=6) ve " öğretmenlerin sözlü beyanları" (f=4) takip etmektedir. " Müdürün, sınıfların canlı derslerine katılması", "iyi uygulamaların paylaşımı" ve "öğrenci ve velilerden gelen dönütler" ise okul müdürlerinin en az başvurduğu (f=1) izleme teknikleri olarak öne çıkmaktadır. 


\section{Tartışma ve Sonuç}

Okul müdürlerinin, COVID-19 sürecinde, eğitim teknolojileri yoluyla uzaktan eğitimi yönetirken, önem sırasına göre çoğunlukla; müfredatın devamını sağlamayı, öğrencilerin okuldan kopmamalarını sağlamayı, öğretmenlerin teknoloji konusunda mesleki gelişimlerini desteklemeyi, akademik başarıyı arttırmayı, öğretmenleri güdülemeyi, uzaktan eğitimle ilgili sorunlara çözüm bulabilmeyi ve okul veli iletişimini sürdürmeyi amaçladığı, araştırmanın birinci alt bulgusunda tespit edilmiştir.

Okul müdürlerinin belirlediği temel amacın müfredatın devamını sağlamakla ilgili olduğu anlaşılmaktadır. Bu durum bir anlamda Harris (2020)'in de belirttiği üzere okul müdürünün insanlarla bağlantıda kalıp, işlerin devamını sağlamaya yönelik bir liderlik davranışı olarak değerlendirilebilir. Okul müdürlerinin teknoloji liderliği yeterlilikleri ile yaşam boyu öğrenme yeterlikleri arasındaki ilişkiyi araştıran Gürkan (2017), teknolojinin eğitimle bütünleştirilmesi konusunda okul müdürünün öğretmenleri, mesleki gelişimlerini destekleyen hizmet-içi eğitimlere teşvik etmesini bu ilişkinin varlığına yönelik bir kanıt olarak değerlendirmiştir. Birinci alt problem kapsamında ulaşılan çarpıcı bir bulgu ise, bir okul müdürünün bu süreci yönetirken okulda uzaktan eğitim kültürü oluşturmayı amaçlamasıdır. Zira bu bulgu, amaç belirleme etkinliği açısından değerlendirildiğinde, diğerlerine oranla daha uzun vadeli bir bakış açısını ortaya koyması açısından farklı bulunmuştur. Buna benzer bir görüşe vurgu yapan Uğur ve Koç (2019), okulun lideri olarak müdürün, okul içinde ve dişında teknolojinin yoğun bir biçimde kullanımını destekleyerek öğretmen ve öğrenciler arasında bir teknoloji kullanım kültürü geliştirebileceğini belirtmiştir. Araştırmanın birinci alt probleminde ulaşılan bulgu, ISTE (2018) eğitim liderleri standartlarıyla da örtüşmektedir. ISTE (2018) eğitim liderleri standartlarına göre eğitim liderleri öğretmen ve öğrencilerin, eğitim ve öğretimi zenginleştirmek için teknolojiyi yenilikçi yollarla kullanmalarını sağlayan bir iklim yaratır, öğretmenlerin teknoloji kullanımı noktasında mesleki gelişimlerini destekler ve öğrencilerin akademik başarısına odaklanır. Araştırmanın birinci alt probleminde ortaya çıkan bulgular ile literatürdeki araştırmaların tespitleri göz önünde bulundurulduğunda, okul müdürlerinin, COVID-19 sürecinde, eğitim teknolojileri yoluyla uzaktan eğitimi yönetmek için müfredatın devamını sağlamayı, öğrencilerin okuldan kopmamalarını sağlamayı, öğretmenlerin teknoloji konusunda mesleki gelişimlerini desteklemeyi, akademik başarıyı arttırmayı, öğretmenleri güdülemeyi, uzaktan eğitimle ilgili sorunlara çözüm bulabilmeyi ve okul veli iletişimini sürdürmeyi amaçladıkları sonucuna ulaşılmıştır.

Araştırmanın ikinci alt problemi kapsamında ulaşılan bulgu, okul müdürlerinin COVID-19 sürecinde, eğitim teknolojileri yoluyla uzaktan eğitimi yönetmek için belirledikleri amaçlara ulaşmalarını engelleyen unsurları sırasıyla en çok; teknik sorunlar, veli duyarsızlığı, öğrencilerin sosyo-ekonomik durumlarının yetersizliği, öğretmenlerin uzaktan eğitime karşı olumsuz tutumları, öğrenci devamsızlığı, anne-babanın ders saatinde evde olmamasından kaynaklı teknolojik araç eksikliği, öğretmenlerin 
aynı zamanda veli olması, evde birden fazla öğrenci bulunması durumunda teknolojik cihazların yetersizliği olarak algıladıklarını göstermektedir. Araştırmalarında benzer sonuçlara ulaşan Gökdaş ve Kayri (2005) uzaktan eğitimde yaşanan sorunları, alt yapı eksiklikleri, ekonomik nedenler, öğrenci ve velilerin bu konuda bilinç düzeylerinin yetersizliği, bölgesel ekonomik farklılıklara bağlı olarak teknolojiden yeterince yararlanılmaması şeklinde belirtmiştir. Gökbulut (2020)'a göre uzaktan eğitimde yaşanan problemlerden bir diğeri ise eğitim veren öğretmenlerden kaynaklanmaktadır. Buna göre, öğretmenlerin bir kısmı yüz yüze eğitimde olduğu gibi etkileşimli dersler işlerken bir kısmı da sadece ders slaytlarını okuyarak, etkileşime yer vermeden derslerini tamamlamaktadır. Bu da öğretmenlerin uzaktan eğitim konusunda deneyimsiz ya da teknoloji kullanımında yetersiz olmalarından kaynaklanabilir. Uzaktan eğitimde deneyimli ve gönüllü öğretmenler ile ders vermek eğitimin başarısını olumlu etkilemektedir (Rasheed, 2007). Araştırma kapsamında elde edilen bulgular ve ilgili alanyazında yer verilen araştırmaların tespitleri dikkate alındığında, okul müdürlerinin COVID-19 sürecinde uzaktan eğitimi yönetmek için belirledikleri amaçlara ulaşmalarını engelleyen faktörlerin başta teknik sorunlar ve veli duyarsızlığı olmak üzere, öğrencilerin sosyo-ekonomik durumunun yol açtığı olumsuzluklar ve öğretmenlerin uzaktan eğitime karşı olumsuz tutumları olduğu sonucuna ulaşılmıştır.

Okul müdürlerinin COVID-19 sürecinde öğretmen ve öğrencilere teknoloji kullanımı noktasında önem sırasına göre en çok; öğretmene teknik destek, okul bilgisayarlarının öğretmenlerle paylaşılması, bakanlık duyurularının paylaşılması, öğretmenlerin teknoloji kullanımına yönelik uzaktan hizmet-içi eğitime yönlendirilmesi, öğrencilerin EBA TV'ye ve EBA canlı derse yönlendirilmesi ve öğretmenler arasında uzaktan eğitime yönelik iyi örneklerin paylaşımını sağlayarak destek oldukları araştırmanın üçüncü alt bulgusunda tespit edilmiştir. Bazı öğretmenler teknoloji destekli sınıflarda ya da uzaktan eğitim uygulamalarında yetersiz kalacaklarını düşündükleri için uzaktan eğitime karşı bir direnç gösterebilirler. Bu öğretmenlere uzaktan eğitim ve öğretim yöntemleri konusunda eğitim verilmesi ya da bu konularda kurslara yönlendirilmeleri öğretmenlerin endişelerini azaltabilir (Cho ve Berge, 2002). Bu nedenle bir uzaktan eğitim lideri eğitim ortamlarında meydana gelen hızlı değişiklikleri izleyebilmeli, teknolojiyi benimsememeli ve süreci yönetme becerisine sahip olmalıdır (Nworie, 2012). Araştırmanın üçüncü alt probleminde ortaya çıkan bulgular ve ilgili alanyazında belirtilen tespitler, okul müdürlerinin COVID-19 sürecinde çeşitli yollarla öğretmen ve öğrencilere teknolojik destek sağladıkları sonucunu ortaya koymaktadır. Araştırmanın dördüncü alt problemi kapsamında elde edilen bulgu, okul müdürlerinin, COVID-19 sürecinde öğrencilerin teknolojik kaynaklara erişiminde eşitliği sağlamak için interneti olmayan öğrencilere kaynakları basılı olarak ulaştırıldıklarını, teknolojik araç gereç temin ettiklerini, EBA kullanımı konusunda destek sağladıklarını ve engelli öğrenciler için özel tedbirler aldıklarını göstermektedir.

İnternete erişim genellikle teknik bir alt yapı sorunudur. Teknik alt yapı sorunlarının çok hızlı bir şekilde giderilmesi kullanıcının sorunlarını en aza indirebilir (Cho 
\& Berge, 2002). Ancak burada bazı öğrencilerin hiç internet erişimi bulunmamaktadır. Bu öğrenciler için okul müdürü ders içeriklerini basılı hale getirerek öğrencilerine ulaştırılmasını sağlamış ve öğrencilerin problemlerini kısmen de olsa çözmüştür. ISTE (2018) standartlarına göre eğitim liderleri öğrencilerin özgün ve ilgi çekici öğrenme fırsatlarına katılmak için gerekli olan teknolojiye erişimlerini sağlar. Bu bilgi, araştırma bulgusunu destekler niteliktedir. Bu bağlamda, okul müdürlerinin kaynaklara erişimde eşitliği sağlamak adına çaba gösterdikleri sonucuna ulaşılmıştır.

COVID-19 sürecinde eğitimin en önemli paydaşlarından olan velilere önemli sorumluluklar düşmüştür. Araştırmanın beşinci alt problemine dayalı olarak elde edilen bulgu, bu süreçte okul müdürlerinin veliler ile yürüttüğü iş birliğini göstermektedir. Okul müdürleri, bu işbirliğini; sosyal medya ve telekomünikasyon araçları yoluyla ve öğrenci ve velilere PDR hizmeti yoluyla sağladıklarını belirtmiştir. Öğrenci başarısını etkileyen faktörlerden bir tanesi de ailedir (Şenel ve Kutlu, 2015). Öğrencinin problemsiz ve başarılı bir şekilde okul hayatını devam ettirebilmesi için velilerin sürekli olarak okul idaresi ve öğretmenlerle iletişim halinde olması büyük önem taşımaktadır. İçerisinde bulunduğumuz dijital çă̆da ise hem öğretmenler hem de ailelerin teknolojiye ayak uydurmaları şarttır (Basit ve Bayraktar, 2016). Günümüzde çalışan veliler, ya da okul ortamına gelerek öğrencisi hakkında bilgi alamayan ailelerin whats-app gibi sosyal medya araçlarını kullanmaları bir çözüm olabilir (Erdem ve Avcı, 2020). Öğrenci velileri yaşanan salgın ve okulların uzaktan eğitime geçmesiyle birlikte başlangıçta nasıl hareket edecekleri konusunda tereddütler yaşamışlardır. Aynı durum okul müdürleri ve öğretmenler için söz konusu olmuştur. Araştırmaya katılan okul müdürleri bu durum karşısında veliler ile iletişim kurma yolu olarak sosyal medya araçlarını (facebook, whats-app vb.) kullandıklarını, bu araçları kullanarak öğrencilerin derslere devam etmelerini sağladıklarını belirtmişlerdir. Pandemi sürecinde yaşanan sorunlardan bir diğeri ise öğrencilere yapılması gereken rehberlik hizmetleri olmuştur. Araştırmada okul müdürleri öğrenci ve velilerin ihtiyaç duydukları rehberlik hizmetlerini rehberlik servisinin telefon üzerinden sağladıklarını belirtmişlerdir. Elde edilen bulgu ve literatürde yer alan araştırmaların tespitlerinden hareketle, okul müdürlerinin COVID-19 sürecinde öğrencilerin uzaktan eğitime katılmasını, çeşitli sosyal medya ve telekomünikasyon araçları yoluyla ve ögrrenci ve velilere yönelik PDR hizmetleri yoluyla sağladıkları sonucuna ulaşılmıştır.

Araştırmanin son alt probleminin bulguları, okul müdürlerinin COVID-19 sürecinde uzaktan eğitimi nasıl izledikleriyle ilgilidir. Elde edilen bulgulardan hareketle, okul müdürlerinin uzaktan eğitim sürecini, EBA üzerinden alınan raporlardan, öğretmenlerden alınan değerlendirme raporlarından, öğretmenlerin sözlü beyanlarından, canlı derslere katılarak, iyi uygulamaların paylaşılmasını sağlayarak ve öğrenci velilerinden gelen dönütleri değerlendirerek izledikleri sonucuna ulaşılmıştır

Kurum yöneticisi olarak okul müdürleri şu ana kadar geleneksel öğrenme ortamlarının yönetim ve organizasyon görevini yürütürken COVID-19 nedeniyle uzaktan 
eğitim liderlik görevini üstlenmek zorunda kalmışlardır. Bu durum okul müdürlerine bu güne kadar karşılaşmadıkları faklı bir alanda sorumluluk yüklemiştir. Araştırmadan elde edilen bulgular, okul müdürünün teknolojik lider olarak COVID-19 sürecinde uzaktan eğitim sürecini yönetmek için öğretmenler, veliler ve öğrencilerle teknoloji temelli bir etkileşim ortamı oluşturduğu genel sonucunu ortaya koymaktadır.

\section{Öneriler}

$\mathrm{Bu}$ araştırma okul müdürlerinin görüşleriyle sınırlıdır. Bu bağlamda eğitimin paydaşları olan veliler, öğretmenler ve öğrencilerin görüşlerini içeren daha kapsamlı araştırmaların yapılması önerilmektedir. Bu araştırmada nitel araştırma deseni kullanılmıştır. Bu konuda nicel ve karma yöntem kullanılan araştırmalar yapılabilir. Araştırmadan elde edilen bulgular, teknoloji kullanımı konusunda zorluk yaşayan öğretmenlerin olduğunu göstermektedir. Bu konuda zorluk çeken öğretmenlere yönelik hizmet-içi eğitimlerin yaygınlaştırılması önerilmektedir. Son olarak, teknolojinin okulda eğitim-öğretim sürecinde kullanılması noktasında en büyük sorumluluğun okul müdürüne düştüğü görülmektedir. Bu noktada okul müdürlerinin eğitim-öğretim süreci kapsamında teknolojiyi kullanmada öncü olması beklenmektedir. Bu nedenle okul müdürlerinin ilk defa ve yeniden atanmasında teknoloji kullanım yeterliklerine ilişkin bir atama kriterinin belirlenmesi politika yapıcılara önerilmektedir.

\section{Kaynakça}

AKBABA-ALTUN, S., ve GÜRER, M. D. (2008). School Administrators' Perceptions of their Roles Regarding Information Technology Classrooms. Eurasian Journal of Educational Research (EJER), (33), 35-54.

AKSOY, M. E., ve ÇOBANOĞLU, L. (2018). Okul Yöneticilerinin Teknoloji Yeterlikleri İle Ulusal/ Uluslararası Projelere Başvuruları Arasındaki İlişki. Electronic Turkish Studies, 13(18), 3139.

ANDERSON, R. E., \& DEXTER, S. (2005). School Technology Leadership: An Empirical Investigation Of Prevalence And Effect. Educational Administration Quarterly, 41(1), 49-82.

BANOĞLU, K., VANDERLINDE, R., ve ÇETIN, M. (2016). Okul Müdürlerinin Teknoloji Liderliği Profillerinin Okulların Öğrenen Örgüt Kültürü Ve Teknolojik Alt-Yapısı Bağlamında Analizi: f@tih Projesi Okulları Ve Diğerleri. Eğitim ve Bilim, 41(188), 83-98

BASIT, O., \& BAYRAKTAR, V. (2016). Technology Use in Family Participation Studies. Current Advances in Education, 743.

BEYTEKIN, O. F. (2014). High School Administrators Perceptions Of Their Technology Leadership Preparedness. Educational Research and Reviews, 9(14), 441-446.

BÜYÜKÖZTÜRK, Ş., KILIÇ ÇAKMAK, E., AKGÜN, Ö. E., KARADENIZ, Ş. ve DEMIREL, F.(2018). Bilimsel Araştırma Yöntemleri. Ankara: Pegem Akademi. 
ÇALIK, T., ÇOBAN, Ö. ve ÖZDEMIR, N. (2019). Okul Yöneticilerinin Teknolojik Liderlik Öz Yeterlikleri ve Kişilik Özellikleri Arasındaki İlişkinin incelenmesi. Ankara Üniversitesi Eğitim Bilimleri Fakültesi Dergisi, 52(1), 83-106

CHANG, I. H. (2012). The Effect of Principals' Technological Leadership on Teachers' Technological Literacy and Teaching Effectiveness in Taiwanese Elementary Schools. Journal of Educational Technology \& Society, 15(2), 328-340.

CHEN, P. S. D., LAMBERT, A. D., \& GUIDRY, K. R. (2010). Engaging Online Learners: The Impact Of Web-Based Learning Technology On College Student Engagement. Computers \& Education, 54(4), 1222-1232.

CHO, S. K., \& BERGE, Z. L. (2002). Overcoming Barriers To Distance Training And Education. USDLA Journal, 16(1), 16-34.

CILLIERS, E. J. (2017). The Challenge Of Teaching Generation Z." PEOPLE: International Journal of Social Sciences, 3(1), 188-198.

DOWNE-WAMBOLDT, B. (1992). Content Analysis: Method, Applications, And Issues. Health Care For Women International, 13(3), 313-321

DURNALI, M. ve AKBAŞLI, S. (2020). Okul Müdürleri Teknolojik Liderlik Davranışlarının Okulda Bilgi Yönetiminin Gerçekleşme Düzeyine Etkisi. Milli Ĕ̆itim Dergisi, 49(225), 23-54.

DURNALI, M. (2018). Öğretmenlere Göre Okul Müdürlerinin Teknolojik Liderlik Davranışları Ve Bilgi Yönetimini Gerçekleştirme Düzeyleri (Doktora Tezi). Hacettepe Üniversitesi, Eğitim Bilimleri Enstitüsü, Ankara.

ERDEM, C. ve AVCI, F. (2020) Okul Öncesi Eğitimde Aile Katılımının Sağlanması için Bilgi İletişim Teknolojilerin Kullanımı: Whatsapp Uygulaması Örneği. Başkent University Journal of Education, 7(2), 439-452.

ESPLIN, N. L., STEWART, C., \& THURSTON, T. N. (2018). Technology Leadership Perceptions of Utah Elementary School Principals. Journal of Research on Technology in Education, 50(4), 305-317.

FLANAGAN, L., \& JACOBSEN, M. (2003). Technology Leadership For The Twenty-First Century Principal. Journal Of Educational Administration.

GÖKBULUT, B. (2020). Distance Education Students' Opinions on Distance Education. In Enriching Teaching and Learning Environments With Contemporary Technologies (pp. 138-152). IGI Global.

GÖKBULUT, B. ve ÇOKLAR, A. N. (2017). Bilişim Teknolojileri Rehber Öğretmenlerinin Teknoloji Koçluk Düzeyleri. TÜBAV Bilim Dergisi, 10(1), 126-138.

GÖKDAŞ, İ. ve KAYRİ, M. (2005). E-Öğrenme Ve Türkiye Açısından Sorunlar, Çözüm Önerileri. Yüzüncü Yıl Üniversitesi Ĕ̆itim Fakültesi Dergisi, 2(2).

GÖRGÜLÜ, D ve KÜÇÜKALİ, R. (2018). Öğretmenlerin Teknolojik Liderlik Özyeterliklerinin İncelenmesi. Uluslararası Liderlik Çalışmaları Dergisi: Kuram ve Uygulama, 1(1), 1-12. 


\section{Covid-19 Sürecinde Okul Müdürlerinin Teknolojik Liderliği}

GÜRFIDAN, H. ve KOÇ, M. (2016). Okul Kültürü, Teknoloji Liderliği Ve Destek Hizmetlerinin Öğretmenlerin Teknoloji Entegrasyonuna Etkisi: Bir Yapısal Eşitlik Modellemesi. Eğitim ve Bilim, 41(188).

GREAVES, T. W., HAYES, J., WILSON, L., GIELNIAK, M., \& PETERSON, E. L. (2012). Revolutionizing Education Through Technology: The Project RED Roadmap for Transformation. International Society for Technology in Education.

GÜRKAN, H. (2017). Okul Müdürlerinin Teknoloji Liderliği Yeterlikleri İle Yaşam Boyu Öğrenme Yeterlikleri Arasındaki Illişkinin Incelenmesi (Yüksek Lisans Tezi), Sabahattin Zaim Üniversitesi, Sosyal Bilimler Enstitüsü, İstanbul.

HACIFAZLIOĞLU,Ö., KARADENIZ, Ş. ve DALGIÇ, G. (2011). Okul Yöneticilerininteknoloji Liderliğine İlişkin Algıları: Metafor Analizi Örneği. Eğitim Bilimleri Araştırmaları Dergisi, 1(1), 97-121.

HAMZAH, M. I. M., NORDIN, N., JUSOFF, K., KARIM, R. A., \& YUSOF, Y. (2010). A Quantitative Analysis Of Malaysian Secondary School Technology Leadership. Management Science And Engineering, 4(2), 124-130.

HARRIS, A. (2020). COVID-19-School Leadership In Crisis?. Journal of Professional Capital and Community.

HERO, J. L. (2020). Exploring the Principal's Technology Leadership: Its Influence on Teachers' Technological Proficiency. Online Submission, 4(6), 4-10.

ISTE-International Society for Technology in Education (2009). ISTE standarts administrators. https://id.iste.org/docs/pdfs/20-14_ISTE_Standards-A_PDF.pdf. Erişim Tarihi: $21 / 08 / 2020$

ISTE-International Society for Technology in Education (2018). https:/ /id.iste.org/docs/Standards-Resources/iste-standards-edleaders_v3.pdf Erişim Tarihi: 25/08/2020

LI, Q., \& MA, X. (2010). A Meta-Analysis Of The Effects Of Computer Technology On School Students' Mathematics Learning. Educational Psychology Review, 22(3), 215-243.

MEB (2020). Bakan Selçuk, koronavirüs'e karşı eğitim alanında alınan tedbirleri açıkladı. https:/ / www.meb.gov.tr/bakan-selcuk-koronaviruse-karsi-egitim-alaninda-alinan-tedbirleri-acikladi/haber/20497/tr'den alınmıştır. Erişim Tarihi: 23/08/2020

MILES, M. B., \& HUBERMAN, A. M. (1994). Qualitative Data Analysis: An Expanded Sourcebook. sage.

NWORIE, J. (2012). Applying Leadership Theories To Distance Education Leadership. Online Journal of Distance Learning Administration, 15(4).

ÖZER, M. (2020). Educational Policy Actions By The Ministry Of National Education In The Times Of COVID-19 Pandemic in Turkey. Kastamonu Eğitim Dergisi, 28(3), 1124-1129.

RASHEED, F. (2007). Factors Impeding Implementation Of Web-Based Distance Learning. AACE Journal, 15(3), 315-338. 
SABAN, A. (2008). Okula İlişkin Metaforlar. Kuram ve Uygulamada Egitim Yönetimi Dergisi, 14(3), 459-496.

SOMYÜREK, S. (2014). Öğretim Sürecinde Z Kuşağının Dikkatini Çekme: Artırılmış Gerçeklik. Eğitim Teknolojisi Kuram ve Uygulama, 4(1), 63-80.

SMITH, J. A. (1995). Semi-Structured Interviewing and Qualitative Analysis. Teoksessa JA Smith. R. Harré and LK Langenhove (toim.) Rethinking Methods in Psychology.

ŞENEL, S. ve KUTLU, Ö. (2015). Ankara Üniversitesi Uzaktan Eğitim Programına Katılan Öğrencilerin Akademik Başarılarını Yordayan Faktörler. Eğitimde ve Psikolojide Ölçme ve Değerlendirme Dergisi, 6(2), 177-193.

UĞUR, N. G., \& KOÇ, T. (2019). Leading and Teaching with Technology: School Principals' Perspective. International Journal of Educational Leadership and Management, 7(1), 42-71.

YILDIRIM, A. ve ŞIMSEK, H. (2011). Sosyal Bilimlerde Nitel Araştırma Yöntemleri Ankara: Seçkin Yayıncilik. 